\title{
Figures and Mirrors in Demetrios Triklinios's Selenography
}

\section{Abstract}

* Some of the ideas elaborated in this article were presented first at the workshop Interstellar Skies: The Lunar Passage in Literature through the Ages (Hven 2018). I am grateful to the organiser and editor of the present journal cluster Dale Kedwards for giving me the opportunity to rediscover Triklinios's fascinating Selenography and for his kindness and patience during the process of writing this piece. I would also like to thank the audiences at Interstellar Skies, the Institute for Research in the Humanities at the University of Bucharest (2018), the 51st Spring Symposium of Byzantine Studies (Edinburgh 2018) and the Summer School of Medieval Philosophy and Culture (Elena 2019) for their valuable feedback. Special thanks go to Tom McLeish who read and reread my translation of the Selenography and helped me understand the 'science concerning the Moon' and to Inmaculada Pérez Martín for her suggestions and continuous support. Similarly, I am grateful to the anonymous reviewers for their attentive reading and productive feedback. Finally, I could not have written this article without the generous support of the Centre for Medieval Literature (University of Southern Denmark and University of York). The initial research for this contribution was conducted as part of the project UMO-2015/19/P/

HS2/ 02739, supported by the National Science Centre, Poland; this project has received funding from the European Union's Horizon 2020 research and innovation programme under the Marie Skłodowska-Curie grant agreement nr. 665778 .
This article* is about the interplay between diagrammatic representation, the mediation of mirrors, and visual cognition. It centres on Demetrios Triklinios (fl. ca. 1308-25/30) and his treatise on lunar theory. The latter includes, first, a discussion of the lunar phases and of the Moon's position in relation to the Sun, and second, a narrative and a pictorial description of the lunar surface. Demetrios Triklinios's Selenography is little-known (though edited in 1967 by Wasserstein) and not available in translation into a modern scholarly language. Therefore, one of the main goals of the present article is to introduce its context and contents and to lay down the foundations for their detailed study at a later stage. When discussing the Selenography, I refer to a bricolage consisting of the two earliest versions of the work preserved in Bayerische Staatsbibliothek, graecus 482, ff. 92r-95V (third quarter of the fourteenth century) and Paris, Bibliothèque nationale de France, graecus 2381, ff. $78 \mathrm{r}-79 \mathrm{v}$ (last quarter of the fourteenth century). I survey the available evidence concerning the role of Demetrios Triklinios (the author), John Astrapas (?) (the grapheus or scribe-painter), and Neophytos Prodromenos and Anonymus (the scribes-editors) in the production of the two manuscript copies. Next, I discuss the diagrams included in the Selenography and their functioning in relation to Triklinios's theory concerning the Moon as a mirror reflecting the geography of the Earth, on the one hand, and to the mirror experiment described by Triklinios, on the other. Finally, I demonstrate how, even though the Selenography is a work on lunar astronomy, it can also be read as a discussion focusing on the Mediterranean world and aiming at elevating its centrality and importance on a cosmic scale.

\section{Prolegomena}

The present article is about the interplay between diagrammatic representation, the mediation of mirrors, and visual cognition. Its discussion is centred on a late Byzantine text on lunar theory that includes, first, a discussion of the lunar phases and of the Moon's position in relation to the Sun, and second, a narrative and a pictorial de-

Interfaces $8 \cdot 2021 \cdot$ pp. 54-73 $\cdot$ DOI 10.54103/interfaces-08-04 
1. I limit myself to two bibliographical examples that are in dialogue with each other. See Nelson; Betancourt, "Why Sight is Not Touch." scription of the lunar surface, thus classifying it as a work of selenology and selenography. As Demetrios Triklinios's Selenography is little-known (though edited in 1967 by Wasserstein) and not available in translation into a modern scholarly language, one of the main goals of the present exposition is to introduce its context and contents to the reader and to lay the foundations for their detailed study at a later stage. The present discussion will also continuously remind the reader of the richness and complexity of Triklinios's treatise. The Selenography introduces knowledge about Earth's oceans and relief (geography, oceanography), about the way the sunlight hits various earthly regions, thus impacting their climate and the skin colour of their inhabitants, about Alexander the Great's campaign in India, and about the properties of air and the casting of shadows. The abundance of topics and areas of knowledge the Byzantine author intertwined while explaining the movement and the appearance of the Moon raises questions about the disciplinary framework underlying his exposition. It also invites the modern reader to reflect on the discipline-specific frameworks and methodologies today's scholarship relies on when approaching Triklinios's Selenography. The present article does not aim to offer an exhaustive analysis of every aspect of Triklinios's treatise and, thus, it will indicate directions of further research whenever appropriate.

Students of Byzantine art have always been interested in the study of light, colour, sight and seeing. They have also inquired into the theories of perception that underpin Byzantine artistic production and the related discourses of vision and cognition based on the interpretation of visual data. ${ }^{1}$ Most recently, historians of Byzantine art widened the scope of their research to include the experience and study of sound and soundscapes (Pentcheva, Hagia Sophia; Pentcheva, Aural Architecture in Byzantium; Gerstel et al., "Soundscapes of Byzantium") and generally, there has been a renewed interest in understanding the sensory and the perceptible in Byzantium (e.g. Ashbrook Harvey and Mullett). In parallel, though rarely in dialogue across disciplines, historians of Byzantine philosophy have also offered accounts and analyses of the theories of perception Byzantium inherited and/or developed (Bydén, Theodore Metochites' Stoicheiosis astronomike 199-210; Bydén, “The Byzantine Fortuna;” Ierodiakonou). Scholars have used various ways of categorising the theories of vision available to the Byzantines and those expounded by them. Nelson, for instance, focused on the dichotomy of theories of extramission (the subject is active and drives the process of visual

Interfaces $8 \cdot 2021 \cdot$ pp. 54-73 
2. For the role of Galen in connecting the philosophical theories of vision with the mathematical, see Ierodiakonou $166-67$. For an illuminating, for a Byzantinist at least, example of the relationship and interplay between contemporary optical and philosophical theories of vision, see the analysis in Jones. I do think that, in the spirit of Jones's piece, it is worth exploring whether Euclidean optics or optical theory in general was thought of by the Byzantine readers as akin to and compatible with physical theories of the visual rays, rather than as a geometrical abstraction detached from the explanations of the 'real life' experience of sight and seeing. perception through the emission of effluences from the eyes) and intromission (the object is motivating the process of seeing as effluences emanating from it are transmitted to the eyes, directly or through a medium; Nelson). Similar categorisation is employed also by Ierodiakonou (Ierodiakonou). Along the same lines Betancourt points out that a number of the existing theories of vision, classical, late antique or medieval, are, in fact, interactionist to a significant degree (Betancourt, Sight, Touch, and Imagination 7-10). Betancourt's analysis aptly and carefully avoids a simplistic bipartition of the theories of vision and, rather than distinguishing extramissionists from intromissionists, speaks of two major groups of Byzantine thinkers influenced by either Plato/Aristotle or by Galen, that is "those who focused on the emission or reception of rays and fires and others who focused on the outpouring and operation of the optic pneuma" (Betancourt, Sight, Touch, and Imagination 9). To them he adds the geometrical accounts of vision offered by Euclid and Ptolemy, as well as the position of the atomists, without emphasising where they stand in relation to the intromission/extramission debate.

Further, ancient and Byzantine theories of vision have also been categorised according to a distinction drawn by the sources themselves, namely as explanations offered by the philosophers (natural philosophical theories, that is, pertaining to the realm of physics) and as theories proposed by the mathematicians (the understanding of sight and vision implicit to optics and catoptrics). ${ }^{2}$ Modern scholarship has also interpreted the ancient and medieval theories of vision as specific to a discipline such as philosophy, optics or medicine (Betancourt, Sight, Touch, and Imagination 29-72). One important assertion Betancourt makes is that in all classical and Byzantine theories of vision discussed in his historical survey sight is mediated. Whether that happens through a transparent medium such as air and water or through effluences emitted from the eyes, the objects of sight or both, in the ancient and medieval physical universe sight happens over distance and it never involves a direct contact between the eye and its object (Betancourt, Sight, Touch, and Imagination 29).

Since the classical and Byzantine theories of vision conceive sight as mediated, it follows that, according to those theories, for sight to occur it is necessary that there is a direct contact between the eye and the medium, on the one hand, and the medium and the object of sight, on the other. In this sense, we should imagine an uninterrupted and clear 'line of sight,' as it were, from the eye through the medium to the object or vice versa. The ways in which one can see

Interfaces $8 \cdot 2021 \cdot$ pp. 54-73 
3. See McCarty. On mentions of mirrors in middle Byzantine texts, see Papaioannou. For a rich survey and further bibliography on mirrors in medieval thought and art see Kessler. On mirrors and mirroring, not as objects or metaphors, but as a "figural dynamic," "a spatial phenomenon" and "a process for structuring a religious and poetic mode of being" in Byzantium, see Pentcheva, "Mirror, Inspiration and the Making of Art in Byzantium." For the most recent and comprehensive overview on mirrors and mirroring in European culture from antiquity to the early modern period, see the essay collection edited by Gerolemou and Diamantopoulou. what falls out of a subject's field of vision are treated by catoptrics, the branch of optics dedicated to the study of mirrors and mirroring. Mirrors, then, add a second degree of mediation in ancient Greek and Byzantine thinking about vision. Mirrors, moreover, can produce images: different types of mirrors can magnify or diminish in scale in order to show a large and distant object entirely, within a much smaller surface, and as if it were much closer to the observer (Gerolemou 158). Mirrors and combinations of mirrors can show what is otherwise unseen, such as the back of the viewer's head. They can also redirect light and hence they can illuminate. Finally, it is the human observer, whether they look at their own reflection or the reflection of something else, and their investment in the process of reflection/creation of images that facilitates the generation of what Willard McCarty dubbed 'metaphorical catoptrics' in classical and medieval literature. ${ }^{3}$ The theories of vision, both philosophical (physics) and mathematical (optics), together with the scientific study of mirrors and reflection (catoptrics) and the literary and metaphorical understanding of mirrors and mirroring will serve the reader in the following discussion of a late Byzantine text on lunar theory. Having positioned the Selenography in its historical and codicological context and having summarized its contents, I will introduce Demetrios Triklinios's theory about the Moon as a reflective surface, a celestial mirror which displays an image of the terrestrial relief and thus performs an important epistemological function, that is, it allows the observer to contemplate and study the inhabited world and its geography. Triklinios continues an ancient tradition concerning the Moon as a cartographical instrument which renders a wide-scoped albeit inverted image of the terrestrial landscape. At the same time, however, as I will argue towards the end of this article, Triklinios modifies the earlier tradition in significant ways which enable us to read the Selenography as an example of a political geography that argues for the centrality of the Mediterranean world.

\section{Whose Moon is it? The Selenography as a brico- lage}

Without entering into the intricate discussion of the nature of medieval authorship, I ought to clarify that, in the present article, what will be referred to as 'Demetrios Triklinios's Selenography' is a bricolage, a collation of several versions of the treatise of different date and

Interfaces $8 \cdot 2021 \cdot$ pp. 54-73 
4. On this point I found Boris and Nicholas Jardine's discussion of eclectic texts and the text as a bricolage especially useful even though the context of their inquiry is the early modern world of printed critical editions: "Another way of putting this is to say that each text is a bricolage, in the technical sense introduced by Claude Lévi-Strauss. That is, a text is not the work of an 'engineer,' produced ex cathedra, fully formed and without material or conceptual links to its historical circumstances; rather it is a piecemeal agglomeration of parts that were 'to hand' for its author, printer, compositors and engravers. This is precisely the history of De revolutionibus. Each text, almost down to the specific individual printed copies - certainly down to those of each penned manuscript — is a 'coming together' of disparate parts. It is therefore ironic that the modern parallel of bricolage, namely the eclectic edition, systematically undermines its object, namely the text as bricolage, destroying it by mirroring its means of construction." (Jardine and Jardine 407).

5. A good starting point for any biographical note on Triklinios is Trapp et al. Prosopographisches Lexikon der Palaiologenzeit (hereafter PLP), no. 29317. A comprehensive account of his life, scholarly and scribal activity with further bibliography is offered by Bianconi 91-118. On the relationship between Triklinios and Thomas Magistros, see Gaul, The Twitching Shroud 263-340 and Gaul, Thomas Magistros. On the relationship between Triklinios and Maximos Planudes, see Wilson 389-94; Reynolds and Wilson 66-68.

6. A reference to the label coined by Ulrich von Wilamowitz-Moellendorff in 1922 and used to designate Maximos Planudes, Manuel Moschopoulos, Demetrios Triklinios and Thomas Magistros as the four philologists of the Palaiologan period. On this point, see Smith 3; also, Gaul, The Twitching Shroud 265. The literature on Triklinios's literary criticism is immense.

7. Wasserstein $153-74$.

8. PLP 23308.

9. For a manuscript description, see Cunningham 367-68. See also Pàmias Massana 19-25 and Caballero Sánchez 47-49. including diverse, though complementary, diagrammatic material. ${ }^{4}$ Further, in my interpretation of the Selenography, I will refrain from reading it as a text authored by Triklinios and accompanied by diagrams. Instead, I will argue for an alternative approach that treats it as a work whose title is a diagram and whose arrangement posits images and words on an equal footing.

Contemporary classicists, well-acquainted with Demetrios Triklinios (fl. ca. 1308-25/30) ${ }^{5}$ and his 'editions' of Aeschylus, Sophocles, Euripides and Aristophanes, Pindar and Hesiod, have seen him as one of their own, a philologist ${ }^{6}$ in the modern sense of the word and even more tellingly, a professional classicist. His interests beyond the realms of poetry and meter have also been documented, though not really discussed. The writing of the Selenography ${ }^{7}$ and the notes found in copies of Maximos Planudes's (ca. 1255-1305) ${ }^{8}$ recension of Aratus's Phaenomena, for instance, in its principal witness Edinburgh, National Library of Scotland [NLS], Adv. 18.7.15, f. 105r (ca. 1290), are usually put forward as examples of Demetrios's astronomical inquiries. The manuscript evidence for Triklinios's interest in Aratus has been best documented by Jean Martin who, at the time, expressed his wish to study the extant bit of the 'Triklinian recension' more accurately at a later stage (Martin xxix-xxxiii). More recently, Jordi Pàmias Massana has argued that the excerpt preserved in Paris, Bibliothèque nationale de France $[\mathrm{BnF}]$, graecus 1310 comes from a Triklinian edition of Eratosthenes's Catasterisms (Pàmias Massana). Triklinios is also known to have revised two astrological po-

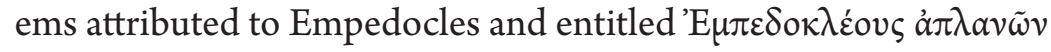

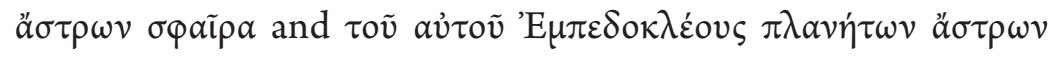
бфаĩpa. Finally, while Daniele Bianconi has persuasively challenged Nigel Wilson's attribution of a marginal note in the copy of Ptolemy's Geography preserved in Città del Vaticano, Biblioteca Apostolica Vaticana [BAV], Urbinas gr. 82 (Bianconi 114), Triklinios's autographical annotations of the Geography have been identified in Oxford, Bodleian Library, Arch. Selden. B. 46, thus demonstrating that he was acquainted with the work. Thus, the pattern emerging from this rather fragmentary evidence supports the idea that Triklinios sustained a systematic interest in the study of the sciences.

The edition of the Selenography in 1967 produced an immediate impact on two accounts; neither concerned the theories about the nature of the Moon. First, the text confirmed a pre-existing hypothesis, namely that Triklinios was a native of the city of Thessaloniki. Second, it mentioned a Thessalonian grapheus ( $\gamma \rho a \varphi \varepsilon v ́ s$, "scribe-painter")

Interfaces $8 \cdot 2021 \cdot$ pp. 54-73 
10. See note 35 .

11. On Eutychios and Michael Astrapas, see most recently Marković; Drpić 334-53; Kuyumdzhieva 496-525. I thank Ivan Drpić for his bibliographical suggestions on the Astrapades.

12. Lovino dates the codex to ca. 1320 . See Lovino 385 . The principal study of the manuscript and its connection to the Astrapades remains Furlan. Most recently, a doctoral dissertation dedicated to the Marcianus was defended at Harvard University; see Cantarella. I thank the author for sharing her work with me before its publication. The proposed association of Triklinios's collaborator with the Astrapas family has been summarized by Griebeler $85-103$. Finally, it is worth bearing in mind a cautious, and rightly so, observation made by Drpić: "Since the word grapheus used by Triklinios can mean both 'scribe' and 'painter', it is not clear whether this John Astrapas exercised his hand in the art of writing or in the art of painting, or perhaps in both. Although his role in Triklinios's project seems to have been primarily to provide scientific illustrations, the possibility that John was a renowned calligrapher must remain open.” See Drpić 347.

13. On the study of the mathematical sciences in Thessaloniki in the thirteenth and fourteenth centuries, see most recently Acerbi and Pérez Martín 1-35. "named after lightning" and possibly called John who seems to have assisted Demetrios in studying and depicting the black figure we see on the Moon. ${ }^{10}$ The expression $\tau \dot{\nu} \nu \tau \tilde{\eta} \varsigma \dot{\alpha} \sigma \tau \rho \alpha \pi \tilde{\eta} \varsigma \dot{\varepsilon} \pi \dot{\epsilon} v v \mu \nu v$ or "named after lightning" makes the identification of Triklinios's collaborator with someone surnamed Astrapas plausible. Further, it may even be hypothesized that the grapheus working with Triklinios belonged to the family (and workshop) of the prolific and prominent Thessalonian painters Eutychios and Michael Astrapas who decorated with frescoes a series of churches in the beginning of the fourteenth century, e.g., the church of the Virgin Peribleptos in Ohrid (1295) and the church of Saint Niketas at Čučer (1321). ${ }^{11}$ Thus, Triklinios's reference to a John Astrapas (?) added yet another facet to the study of one of the best-known Byzantine artistic workshops. Usually, scholars have also added to this catalogue the note found on $\mathrm{f}$. $1 \mathrm{r}$ in the richly illustrated Venezia, Biblioteca Nazionale Marciana [BM], graecus Z. 516 (first half of the fourteenth century) which suggests that a certain maïstor Astrapas was the owner of this copy of Ptolemy's Geography. ${ }^{12}$ The early fourteenth-century Thessaloniki and the artistic workshop of the Astrapades provide an important backdrop for Triklinios's Selenography and should not be dismissed. ${ }^{13}$ Nonetheless, it is hardly possible to confirm that a John Astrapas (?) was indeed a member of the workshop. Moreover, a comparison of the two earliest manuscript witnesses preserving the Selenography reveals both diagrammatic and textual discrepancies which, in turn, make establishing the precise role of the scribe-painter in executing the illustrations particularly challenging as I will show in the final section of my analysis.

As stated earlier, when discussing the Selenography, I refer to a collation, a bricolage consisting of the versions of the work as found in its two earliest copies. The master copy of Triklinios is probably to be found somewhere at the intersection of both; at the same time, however, the differences in layout and elements of textual organisation (such as titles and subtitles) speak for the relevant autonomy behind the 'editorial' decisions of the main scribes who designed and executed both manuscripts. Therefore, next, I shall briefly introduce the manuscripts and the scribes.

\section{BSB 482 and Neophytos Prodromenos}

The manuscript containing the earliest extant copy of the Selenography - München, Bayerische Staatsbibliothek [BSB], graecus 482

Interfaces $8 \cdot 2021 \cdot$ pp. 54-73 
14. A black and white digital reproduction is available here: web; accessed on 24 August 2021.

15. For a detailed description of BSB 482, see Caballero Sánchez 95-98. For the dating of the manuscript and for Prodromenos as a copyist of Aristotle, see Mondrain, "La constitution de corpus d'Aristote" 15 , note 18 . The oldest codicological unit (ff. $96 \mathrm{r}-172 \mathrm{v}$ ) of BSB 482 dates to the third quarter of the thirteenth century and contains Nikomachos of Gerasa's Introduction to Arithmetic. This section, annotated by Prodromenos, was used to form the core to which new quires (and texts such as Cleomedes's The Heavens) were added in order to create what is now BSB 482.

16. PLP 22235. See also, Acerbi, "Byzantine Recensions" 183; and, most recently, Caballero Sánchez 21-34.

17. PLP 19254. On Neophytos, see, for instance Mondrain, "Copier et lire." On his scribal practices and editorial decisions in terms of layout, reference systems and decoration, see Cacouros. Finally, on another aspect of his diagrammatic program in BSB 482 illustrating Eratosthenes's procedure of measuring the Earth's circumference, see my forthcoming "Space, Place, Diagram." For the edition of the botanical lexicon attributed to Neophytos Prodromenos, see Lundström, and Mondrain, "Un lexique botanico-médical.”

18. Caballero Sánchez 98.

Figure 1. A circular diagram of the zodiac and the phases and aspects of the Moon, including a zonal world map. Paris, Bibliothèque nationale de France [BnF], graecus 2381, f. 78 r. Photo courtesy of the Bibliothèque nationale de France, Paris. (henceforth BSB 482) ${ }^{14}$ - is composed of two codicological units of different date. ${ }^{15}$ The posterior one (third quarter of the fourteenth century) contains Cleomedes's The Heavens, John Pothos Pediasimos's (ca.1240-1310/14) commentary, ${ }^{16}$ and Demetrios Triklinios's Selenography (ff. 92r-95v). The codex results from the scribal, editorial, and restoration activity of the scholar-scribe Neophytos Prodromenos (fl. 1329/1339-77). ${ }^{17}$ Prodromenos collaborated with three other scribes on BSB 482 and Paula Caballero Sánchez has attributed to him also the execution of the diagrams associated with the works of Cleomedes and Pediasimos. ${ }^{18}$ The BSB 482 layout, including the inclusion of a titular diagram, may have been derived from Triklinios's 'master copy', but there is no way of confirming or rejecting this hypothesis. What can be said, however, is that BSB 482 preserves the version resulting from the editorial efforts of Prodromenos and that it is quite probable that we owe the current arrangement to him. Thus, with a reference to the idea of the Selenography as a bricolage, the reader may wonder whether the Selenography, as found in the BSB 482, is the product of Triklinios's design or rather of that of Neophytos.

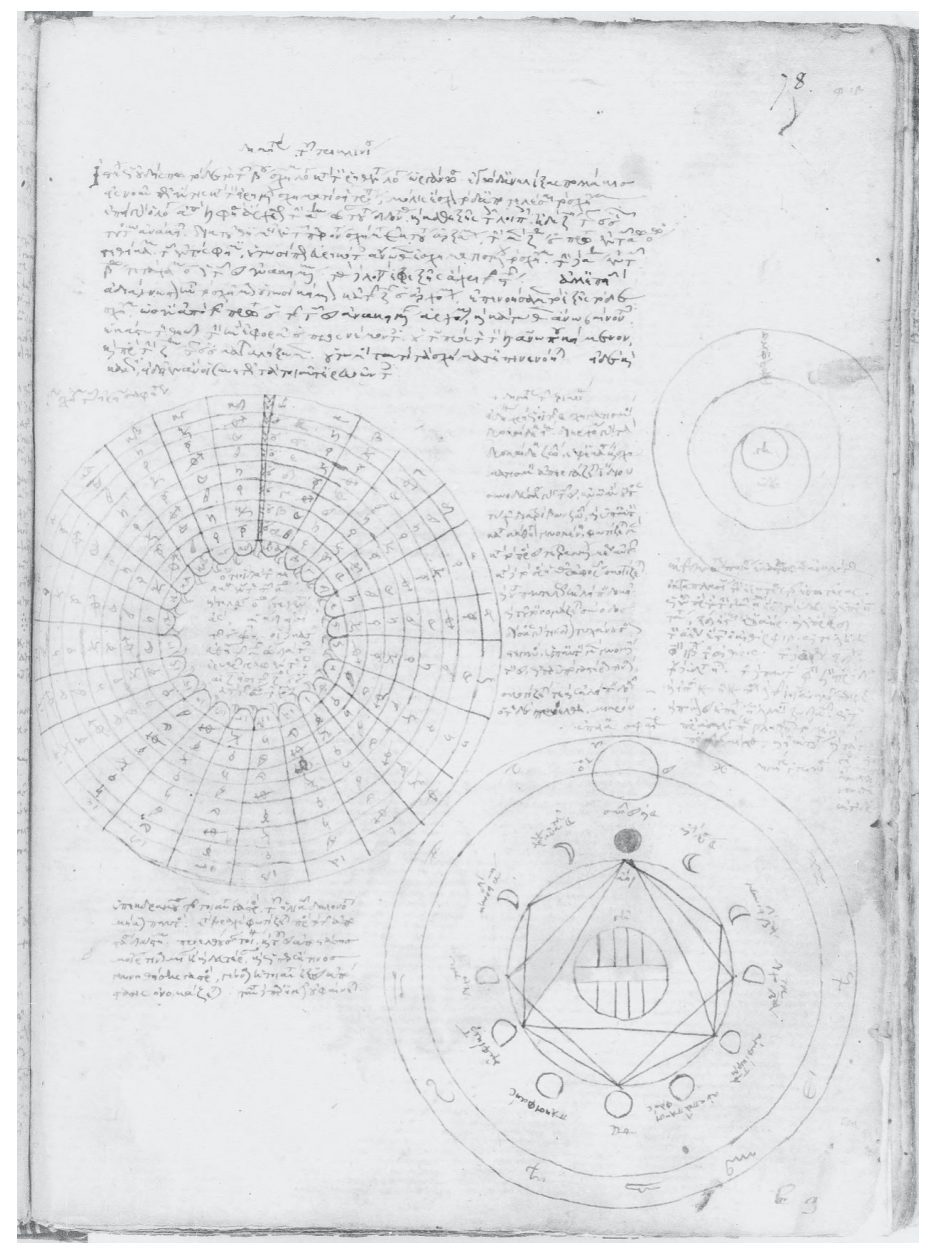

Interfaces $8 \cdot 2021 \cdot$ pp. 54-73 


\section{BnF 2381 and the Anonymus}

19. A black and white digital reproduction is available here: web; accessed on 24 August 2021.

20. The most recent description of the codex is available in Caballero Sánchez 107-10. Eleuteri notes the interventions of two hands; Caballero Sánchez focuses on the hand of the scribe responsible for the copy of Cleomedes, Pediasimos and Triklinios. She associates him with the circle of the so-called 'anonymous digraphic scribe.' The latter was active in the 1380 s and his hand has been recorded by Mondrain in eleven manuscripts. See, Mondrain, "Les écritures" $189-96$. For the contents of $\mathrm{BnF} 2381$, see Boudreaux CCAG, vol. VIII, 3, 43-59.

21. I provide a detailed comparative analysis of both diagrams in my forthcoming monograph.

22. At present, we know of more copies of Triklinios's treatise than those consulted by Wasserstein for the preparation of his critical edition. They are all later than the Monacensis and Parisinus, on which I rely for the present article. I have consulted those currently available through a digital reproduction and only one of them contains the second diagram depicting the lunar surface, namely the sixteenth-century Milano, Veneranda Biblioteca Ambrosiana [VBA], C 263 inf. A digital version in colour is available at Biblioteca Digitale della Veneranda Biblioteca Ambrosiana; accessed on 31 August 2021. This codex preserves both diagrams associated with the Selenography on ff. $302 \mathrm{~V}$ and $304 \mathrm{r}$ respectively. In terms of their design, both follow the model of $\mathrm{BnF} 2381$; I discuss them in my forthcoming monograph. For a comprehensive understanding of the transmission of the work (text and diagrams) and the variations in layout and textual organisation further work on the remaining manuscript witnesses is needed.
Paris, Bibliothèque nationale de France $[\mathrm{BnF}]$, graecus 2381, ff. 78r$79 \mathrm{v}$ (henceforth $\mathrm{BnF} 2381)^{19}$ is important for the understanding of the Selenography on two grounds. First, it is the second earliest extant copy of the work; and second, it includes, unlike BSB 482, both the titular diagram of the lunar phases (f. 78 r, figure 1 ) and a second diagram depicting the lunar surface and the 'dark shadow' we see on the Moon (f. $78 \mathrm{v}$, figure 4). I will return to a discussion of the diagrams later on.

This paper codex was produced during the last quarter of the fourteenth century, and it is thus younger than BSB 482, but not by much. It preserves the hands of two main, contemporary scribes. ${ }^{20}$ Eleuteri dates it to ca. 1371 based on the information contained in the astronomical tables on ff. 10or and 101r (Eleuteri 86). The analysis of the watermarks - spanning between ca.1364-93 - also indicates a production date towards the end of the fourteenth century. The manuscript contains numerous texts, mostly on mathematics and astronomy, including Cleomedes's The Heavens and Triklinios's Selenography (ff. $78 \mathrm{r}-79 \mathrm{v}$ ). The latter is copied by a single scribe, to whom I refer throughout this article as Anonymus. To him we owe the differences in comparison with BSB 482 in terms of layout, section titles in the body of the text and in the margins, as well as the selection of diagrams. Folio $78 \mathrm{r}$ (figure 1) includes the titular diagram from BSB 482, f. $92 \mathrm{r}$ (figure ${ }_{3}$ ) and modifies it in some significant respects including its position in relation to the beginning of the Selenography. ${ }^{21}$ Folio $78 \mathrm{v}$, in turn, includes a diagram - possibly a version of the study of the lunar surface Triklinios and the Thessalonian grapheus worked on. This image (figure 4) invariably captures the imagination of scholars working on the Selenography today but it must be said that it is omitted from the earliest manuscript witness BSB 482. Further research is needed to answer the question as to why the diagram of the lunar surface was not copied in BSB 482 and in what ways its omission influenced the intelligibility of the related part of the text. In the meantime, it suffices to bear in mind the complexities of the preservation and transmission of the Selenography. ${ }^{22}$

In the present discussion I rely on $\mathrm{BnF} 2381$ in three aspects. First, as it displays a different layout and textual organisation from BSB $482, \mathrm{BnF} 2381$ provides the necessary backdrop against which it becomes evident that the choices made by Prodromenos are deliberate and meaningful and that he could have made alternative editorial decisions. Second, $\mathrm{BnF}_{23} 81$ is the most important and earliest witness

Interfaces $8 \cdot 2021 \cdot$ pp. 54-73 
23. A digital version in colour is available at Internet Culturale; accessed on 24 August 2021.

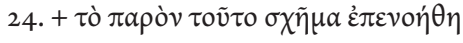

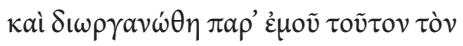

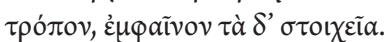

25. A version of this diagram and accompanying note attributing it to Triklinios is preserved also on $\mathrm{f}$. $311 \mathrm{r}$ of VBA, ms. C 263 inf.

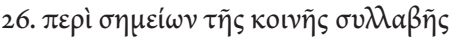

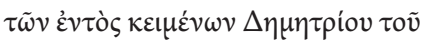

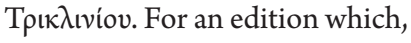
however, does not take into account the copy in the Parisinus, see Dindorf $43-44$.
Figure 2. A circular diagram of the four elements and their physical properties. Paris, Bibliothèque nationale de France [BnF], graecus 2381, f. 66r. Photo courtesy of the Bibliothèque nationale de France, Paris. for John Astrapas's (?) study of the lunar surface which, in turn, is essential for any reading of the Selenography. Third, BnF 2381 provides further evidence to support the hypothesis that Triklinios was invested in equipping his texts with diagrams and illustrations. His oftenmentioned autograph copy of Hesiod's Work and Days - Venezia, Biblioteca Nazionale Marciana [BM], gr. Z. 464 (coll. 762) dated to 1316-19 - boasts two high-quality illustrations of a young boy using mortar, and a ploughman, his cattle and tools on the opening of ff. $33 \mathrm{~V}$ and $34 \mathrm{r}^{23}$ In addition to the Selenography, $\mathrm{BnF} 2381$ also contains an excerpt from the Hexaemeron of Basil accompanied by a diagram (f. 66r, figure 2). Jean Martin attributed the latter to Triklinios because it is featured in the sylloge of Aratean material very probably compiled by the Thessalonian (Martin xxxii). The first line on the folio contains a note which refers to the diagram, its author and content: "This present diagram was conceived and its elements arranged by me in such a way that it displays the four elements." ${ }^{24}$ Then follows the excerpt and the featured circular diagram of the four elements (clockwise: fire, air, water, and earth), each with their respective set of qualities (e.g., fire is labelled as dry and hot). ${ }^{25}$ Next on line 37 one finds the beginning of Triklinios's prolegomena to Aristophanes (f. 66r, 1l. 37-58). ${ }^{26}$

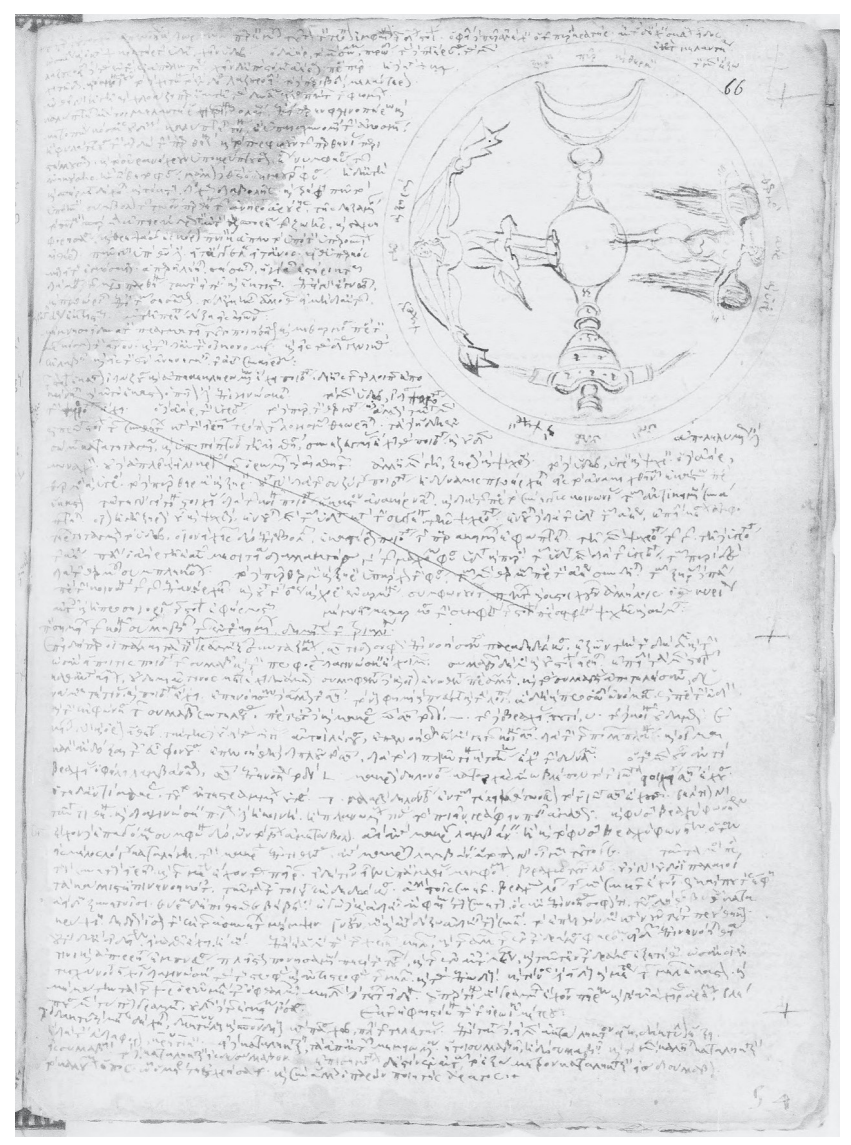

Interfaces $8 \cdot 2021 \cdot$ pp. 54-73 


\section{The Selenography: Summary of content and diagrams}

27. At present, the most detailed summary and the most profound scholarly engagement with Triklinios's Selenography is still that by its editor Abraham Wasserstein, published in 1967. On Triklinios's Selenography, see most recently Acerbi and Pérez Martín, "Les études géométriques” 11-13 and Pérez Martín and Manolova, "Science Teaching” 102-03. The Selenography is briefly discussed also by Lazaris 69 and fig. 16.

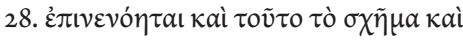

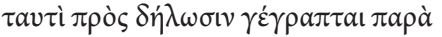

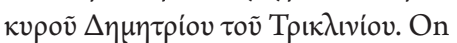
Prodromenos adding this phrase, see Acerbi and Pérez Martín, "Les études géométriques" 13.
Figure 3. A circular diagram of the zodiac, the phases and aspects of the Moon. Bayerische Staatsbibliothek München, Cod. graec. 482, fol. 92r, urn:nbn:de:bvb:12bsbooo76120-5. Photo courtesy of the Bayerische Staatsbibliothek, Munich.
Having surveyed the available evidence concerning the role of Demetrios Triklinios (the author), John Astrapas (?) (the grapheus or scribe-painter), and Neophytos Prodromenos and Anonymus (the scribes-editors) in the production of BSB 482 and $\mathrm{BnF} 2381$, in this section I proceed by summarising the contents of the Selenography. ${ }^{27}$

As found in its earliest copy, the BSB 482, the Selenography starts with a diagram of the zodiac and the lunar phases (figure 3 ). Just below the diagram, Neophytos Prodromenos has supplied the following subscription: "This figure was conceived and these [lines] written by kyr Demetrios Triklinios for the sake of explanation. ${ }^{28}$ Next follows the main body of Triklinios's text. The first thematic unit (Wasserstein 162-63, 11. 1-50) introduces twelve lunar phases, the technical terms associated with them, and the notion of conjunction. The lunar phases are correlated with the twelve divisions of the zodiac and the passage of the Moon through it, that is, across the back-

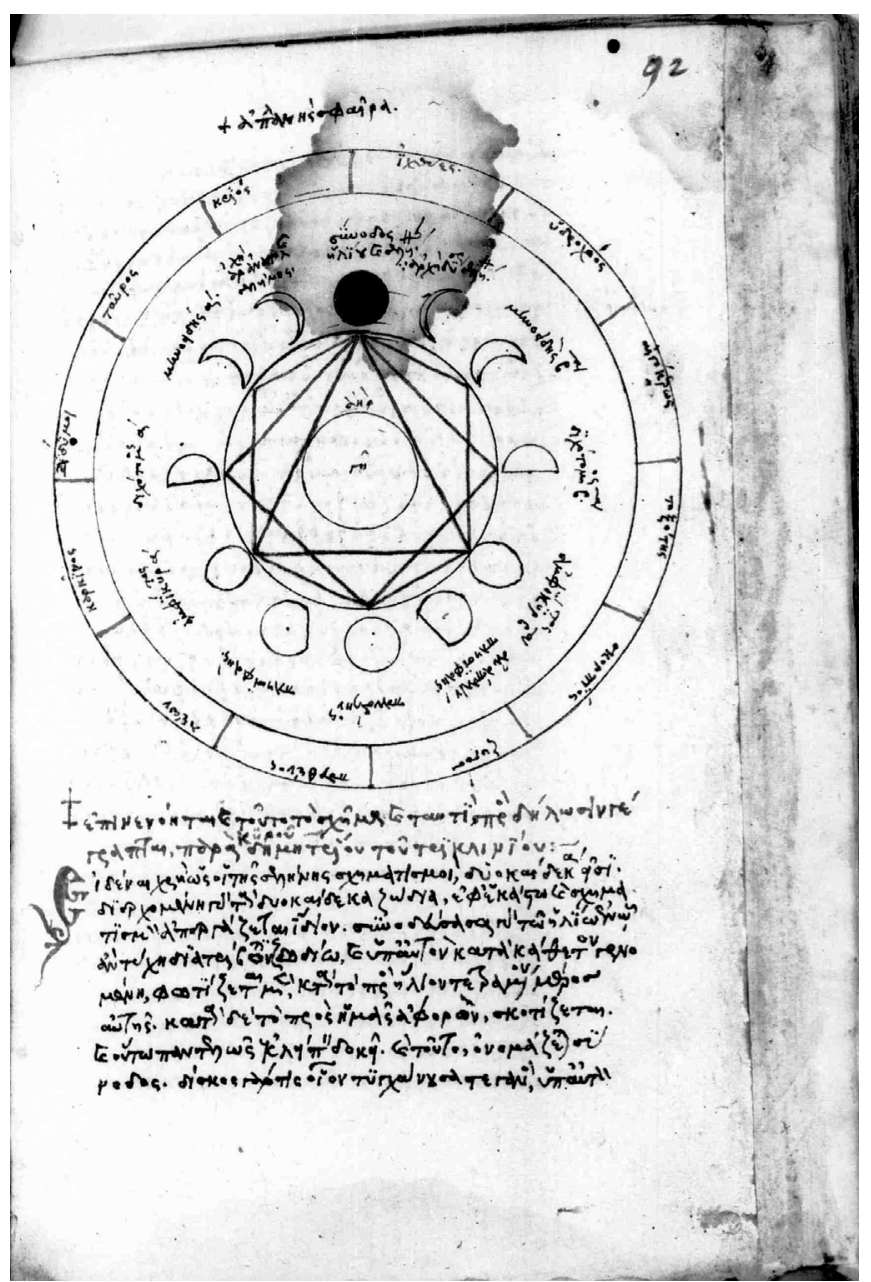


29. Just as with the introduction of twelve lunar phases, Triklinios's observations on the apparent rotation of the markings on the lunar surface are fairly unusual and, to my knowledge, unique in the Byzantine tradition. They are closely paralleled, however, by the remarks made by Triklinios's rough contemporary the Parisian teaching master John Buridan (ca. 1300-after 1358). I explore both accounts in detail in my forthcoming monograph. ground of the fixed stars. Then, Triklinios provides an explanation of the lunar aspects (11.51-60). Next, the Thessalonian postulates i) that the Moon lies between the elemental spheres of air and aether and is the junction of both (11. 61-62); ii) that the Moon is a reflective and a mirroring surface (1.62); iii) that it does receive the impressions of the Earth's relief and oceans (11. 62-63) and iv) that we therefore see a black figure on its surface (11.63-64). After referring to the collaboration with the Thessalonian grapheus on rendering the lunar surface in a diagram, Triklinios goes on to explain that as the sea in the inhabited part of the Earth is shaped as a human figure, so too is its reflection on the Moon. Both figures have respective inverted east-west orientation as one is the reflection of the other. Further, Triklinios states that, thanks to Homer and some other geographers, we know that there is an ocean that encircles the entire Earth, whereas according to Ptolemy, there is an ocean located in the west. Their shadows are not to be seen on the Moon, as the lunar body is half the size of the Earth and therefore, its surface is not sufficiently large to display the full reflection of the terrestrial relief (11. 64-82).

Having explained why we see a dark human shape on the lunar surface, Triklinios proceeds by describing the apparent rotation of the figure on the Moon as it traverses the sky (11. 83-100) ${ }^{29}$ According to him, during full moon, the figure appears standing upright at moonrise; outstretched sideways, as if lying down, at moonset; upside down, that is with feet towards the north pole, when below the horizon; and again upright and head towards the north at the next moonrise. The next section (11. 101-35) commences with Triklinios explaining the correspondences between different parts of the black humanoid figure on the lunar surface and the known terrestrial seas, e.g. the sea around Cadiz corresponds to the head, the Ionian Sea is reflected by the figure's right hand, and so forth. Triklinios makes several observations about the geographical position of Cadiz and the Mediterranean, as well as of the lands inhabited by the Indians and the Ethiopians. The significance of this geo-ethnographical discussion is at least twofold. First, it testifies to the complementarity of the scientific fields of astronomy and geography in Byzantium. Second, it suggests that the rationale for Triklinios's observations of the lunar surface is geo- and therefore anthropocentric: understanding the dark figure on the Moon is meaningful as a scientific endeavour insofar as the figure is a reflection of the terrestrial oceans. Hence, by observing our (our sea's) reflection in the mirror of the Moon, we may learn about ourselves, or, in the case of Triklinios, about the position of his Mediterranean within the inhabited world.

Interfaces $8 \cdot 2021 \cdot$ pp. 54-73 
30. I provide a detailed discussion of Triklinios's description of a mirror experiment in my forthcoming monograph. At this point, it suffices to draw the connection between the Selenography and Cleomedes's The Heavens II. 4.18 (I thank one of the anonymous reviewers for this suggestion!) which mentions that mirrors and bright silver objects have been used to show that the Moon is both illuminated by the Sun and illuminates the air by reflection. Cleomedes goes on to reject the possibility of the Moon illuminating by reflection, hence it is interesting to analyse the extent to which Triklinios takes his cue from The Heavens and the ways in which he departs from it.

31. BSB 482, like most medieval codices, does not require nor ensure a linear reading. At the same time, Prodromenos's editorial programme, including the design and placement of the diagrams across the Cleomedes-Triklinios section, suggests that the hypothesis for a continuous reading is plausible. The organization of the material in $\mathrm{BnF} 2381$ is markedly different from that of BSB 482 and requires further research beyond the scope of the present article. It should be said, however, that the diagrams accompanying Cleomedes's text in the Parisinus (ff. 47r-62r) do not treat the lunar phases at all. A couple of cosmological diagrams (on ff. 48r and 49r), however, incorporate a zonal map of the Earth of the same type as the one featured in the Selenography's titular diagram on $\mathrm{f}$. $78 \mathrm{r}$ in $\mathrm{BnF} 2381$. The later copy VBA, $\mathrm{C}_{2} 63$ inf. also features a zonal map on $\mathrm{f} .302 \mathrm{~V}$ as part of the titular diagram. I provide a detailed analysis of the zonal maps in the Parisinus and the Ambrosianus and interpretation of their connection to Triklinios's treatise in my forthcoming monograph.
The following section (11.136-52) returns to the topic of the observational experiment Triklinios claims to have conducted with the help of a mirror. First, he acknowledges that he is not able to confirm whether the dark anthropomorphic figure remains on the lunar surface when the Moon is below the Earth and possibly in its shadow. Then, he details how his mirror observation might be repeated. ${ }^{30}$ The final section (11. 153-80) of the Selenography refutes the hypothesis that the dark figure on the lunar surface is a shadow cast by the air. Among the series of arguments, it is worth mentioning that here Triklinios remarks that the shapes we see on the lunar surface always remain the same and hence they cannot be shadows cast by the perpetually moving air.

\section{The titular diagram}

In the earliest extant copy of the Selenography - BSB 482 (third quarter of the fourteenth century), ff. $92 \mathrm{r}-95 \mathrm{v}$ - the treatise opens with a titular diagram (f. 92r, figure 3 ) rather than a heading or a sentence. The diagram depicts the twelve lunar phases defined and explained by Triklinios in the following exposition.

The titular diagram in BSB 482 (f. 92r) depicts twelve lunar phases which is by itself unusual as commonly only eight are depicted. It provides the appropriate name for each one and positions them within a spatial and temporal relationship within the zodiac and in terms of their position with respect to the Sun and the Earth. All elements of the diagram are functional in relation to the explanation provided hereafter and are easily unpacked, especially if one reads the codex in a linear fashion starting with Cleomedes's The Heavens and the accompanying scholia by John Pediasimos..$^{31}$ In fact, the manuscript presents several simpler diagrammatic representations of the lunar phases preceding Triklinios's text. Thus, f. $58 \mathrm{r}$ contains a depiction of the Moon and the Sun and two of the lunar phases accompanied by their technical labels, namely $\mu \eta v o \varepsilon \_\delta$ ' ("crescent") and

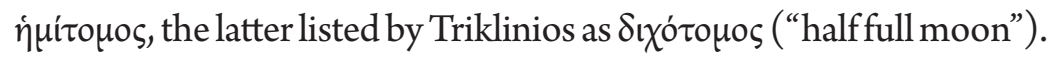
The back of the folio (f. $58 \mathrm{v}$ ) includes a depiction of the full moon ( $\pi \lambda \eta \dot{\rho \eta}$ ) as the final element in the series. Next, f. 61r lists another set

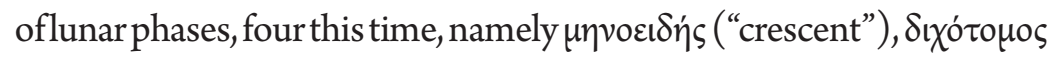

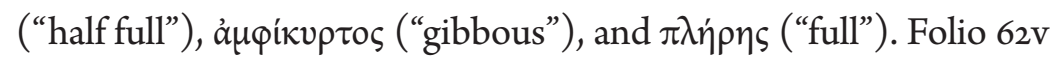
lists four phases again, f. 63v depicts the circular path of the Moon as it revolves around the Earth, and finally, f. 64r illustrates the lunar eclipse,

Interfaces $8 \cdot 2021 \cdot$ pp. 54-73 
32. See note 14 for a link to the digital reproduction of the BSB 482 .
33. Such a reading proceeds from the general and all-encompassing outer sphere to the Earth positioned in the centre of the universe. The same can also be viewed as a progression from the outer and moving spheres towards the static and unmoveable Earth in the centre. The fifteenth-century codex Firenze, Biblioteca Medicea Laurenziana [BML], Plut. 86.14, for instance, features on $\mathrm{f}$. $137 \mathrm{v}$ a planetary diagram in which the sphere of Saturn is labelled as first and that of the Moon as seventh in order. A digital reproduction in colour is available at Biblioteca Medicea Laurenziana, Digital Repository; accessed on 24 August 2021. On the Laurentianus, see Caudano 1-25. Numbering and, by extension, reading a planetary diagram reversely, that is from the centre towards the periphery, is also attested, as for instance in BAV, Vaticanus graecus 211, f. 115V which features nine spheres. A black and white digital reproduction is available at DigiVatLib, The Vatican Library; accessed on 24 August 2021. thus showing for the first time in this codex the relationship between the Earth, the Moon, and the Sun within the zodiac. ${ }^{32}$

This is the pre-existing visual material regarding the phases of the Moon that the reader could have been exposed to within the context of BSB 482 and before reading Triklinios's essay. As a result, the reader could have already been familiar with the shape of and the vocabulary regarding four of the lunar phases, and how each one is defined according to the Moon's position in relation to the Sun. In addition to this, Triklinios's diagram depicts twelve phases and positions them within the zodiac, thus depicting the Moon's complete movement around the Earth. The zodiac is represented in the diagram's outer register running counterclockwise. Each constellation's name is written in full, symbols and figurative depictions are not supplied. Aries (кpı́s) is positioned at the top thusindicating the beginning of the astronomical year. Further, Aries is aligned with the conjunction of the Moon and the Sun and the phase of the new moon in the middle register of the diagram, as well as with the labels identifying the elemental sphere of the air (án $\rho$ ) and the earth $(\gamma \tilde{\eta})$ in the diagram's centre (figure 3 ).

One common way of reading cosmographical diagrams in Byzantine manuscripts depicting some or all of the planetary spheres involves moving from the first and outer sphere of the fixed stars (which coincides with the band of the zodiac and encompasses all other spheres) towards the innermost spheres of the Moon and the elements. ${ }^{33} \mathrm{BSB} 482$, f. $92 \mathrm{r}$ follows the same logic which, in turn, is replicated in Triklinios's narrative. Namely, one should read the diagram starting from its outer register towards its centre. In the text, Triklinios defines first the lunar phases according to the movement of the Moon from zodiacal sign to zodiacal sign and only then moves to discuss three of the aspects of the Moon, namely sextile, quartile and trine, which are depicted as the respective geometrical shapes within the diagram's middle register. Finally, as he goes on to explain the black shadow visible on the lunar surface, the position of the Moon between the elements of air and aether plays a role in Triklinios's reasoning, as noted within the titular diagram by the indication of the sphere of air just above the Earth and below the sphere of the Moon.

In sum, the opening diagram in BSB 482 (figure 3 ) first builds on, synthesizes, and upgrades the knowledge concerning the lunar phases transmitted by simpler diagrammatic lists featured earlier in the manuscript. Second, it condenses the knowledge provided by the first part of Triklinios's essay dedicated to lunar phases and aspects. Third, the diagram reads from periphery to centre and thus prepares

Interfaces $8 \cdot 2021 \cdot$ pp. 54-73 
Figure 4. A diagram and a study of the dark figure on the lunar surface. Paris, Bibliothèque nationale de France [BnF], graecus 2381, f. 78v. Photo courtesy of the Bibliothèque nationale de France, Paris. us for the second half of the Selenography. While discussing the black figure on the lunar surface, which mirrors and is a mirror image of the Earth's seas and oceans, Triklinios in fact directs the readers' gaze back towards the Earth, towards 'their' inhabited world and 'their' seas. Not coincidentally, this is also the part in which Triklinios describes his mirror experiment, thus narrowing his focus on the human subject, earthbound yet nevertheless able to replicate the Moon's reflective power through their art and artifice.

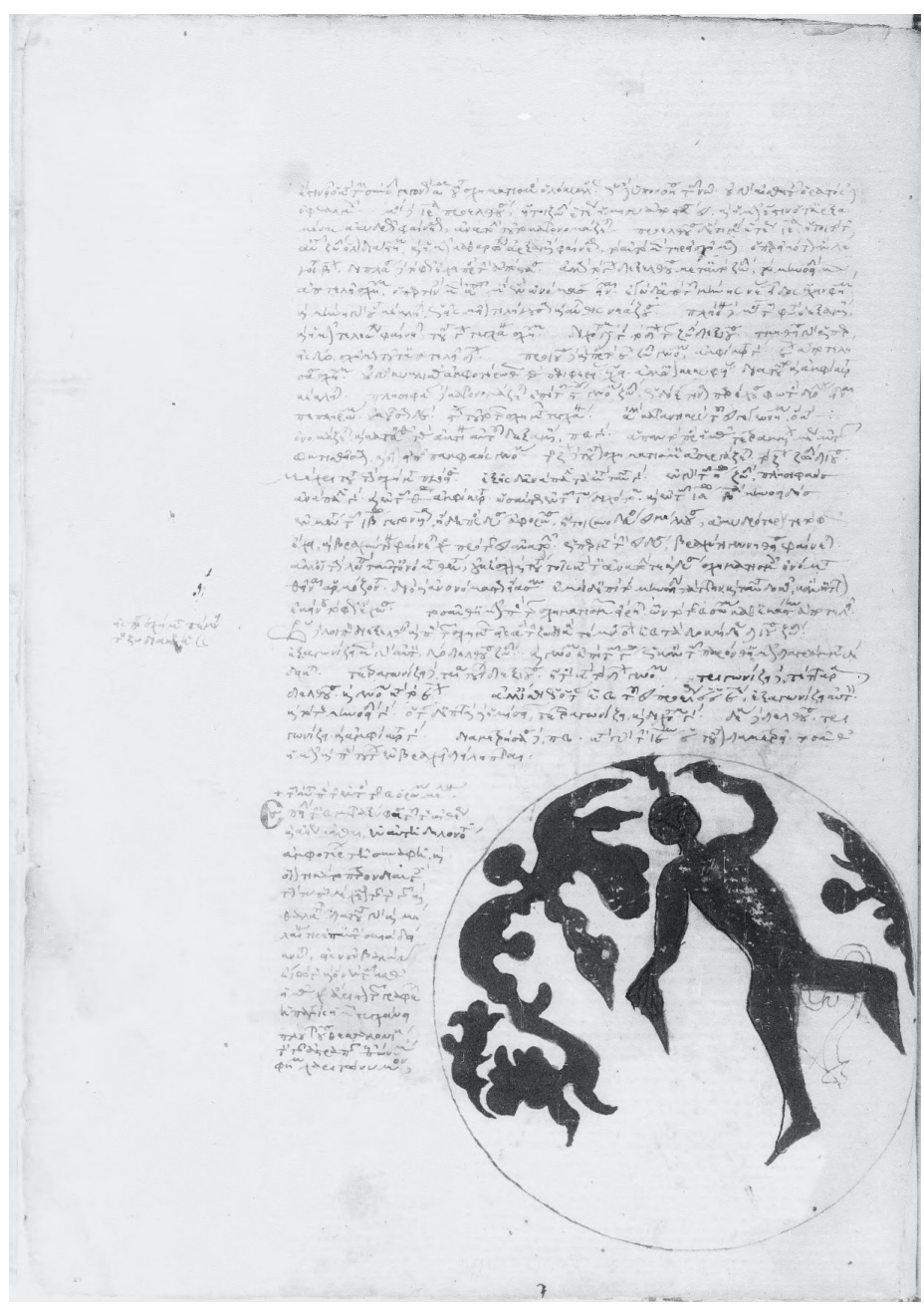

\section{A Study of the lunar surface or'The man on the Moon'}

The initial diagram preserved in the Monacensis stops being functional with respect to the narrative when Triklinios moves on to describe the dark figure visible on the lunar surface: 
34. Triklinios is being purposefully (?) ambiguous here as the primary meaning of бкı́a denotes 'shadow' while a secondary meaning refers to 'a reflection, a mirror image.' In terms of its graphic properties and its depiction as in the second diagram in $\mathrm{BnF} 2381$, f. $78 \mathrm{v}$ (figure 4), the anthropomorphic figure is certainly represented as a shadow rather than a reflection. The latter, traditionally, is rendered geometrically as a subject of catoptrics, rather than in pictorial and figurative terms. At the same time, one ought to bear in mind that shadows are significant in an astronomical context (consider the discussion of lunar and solar eclipses) and this is certainly the context of the Selenography. Triklinios's argument, however, clearly invokes and relies upon the secondary meaning of

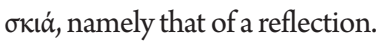

35. I translate this passage with caution so as not to impose the interpretation that "the one named after lightning" ( $\dot{\alpha} \sigma \tau \rho \alpha \pi \tilde{\eta} \varsigma \dot{\varepsilon} \tau \omega \dot{v} v v \mu \nu v)$ is necessarily a member of the Astrapas family or that the epithet $\chi \propto \rho \iota \tau \dot{v} v v \mu$ os points unequivocally to someone named John. Nevertheless, I should note that I consider this interpretation of the wordplay employed by Triklinios plausible. The interested reader may find an explanation of the name 'I $\omega \alpha \dot{v} v \eta\rceil$ s as a rendering of the Hebrew for 'grace' in John Tzetzes's Chiliades. According to the Lexikon zur byzantinischen Gräzität, the use of $\chi \propto \rho \iota \tau \dot{v} v \mu$ os and its cognates denoting "someone named John" is attested from the twelfth century onwards in Byzantine authors such as Tzetzes, Theodore Prodromos, Manganeios Prodromos and Niketas Eugenianos. At the same time, I have not been able to find the expression $\tau \dot{v} v \tau \tilde{\eta} \varsigma$ $\dot{\alpha} \sigma \tau \rho \alpha \pi \tilde{\eta} \varsigma \dot{\varepsilon} \pi \dot{\omega} v v \mu \rho v$ anywhere but in Triklinios's Selenography.

36. Wasserstein, "An Unpublished Treatise” 163-64, lines 61-73: $\dot{\alpha} \lambda \lambda^{\prime} \dot{\varepsilon} \pi \varepsilon 1 \delta \dot{\eta}$

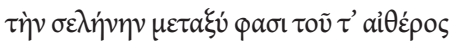

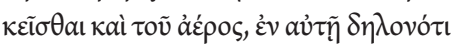

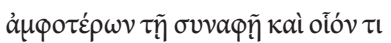

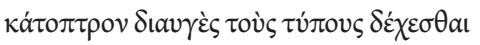

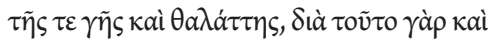

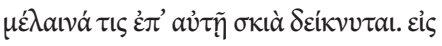

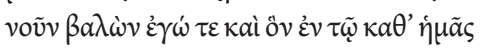
$\chi \rho o ́ v \omega$ ă

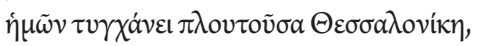

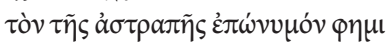

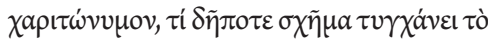

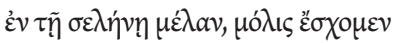

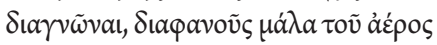

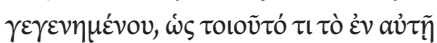

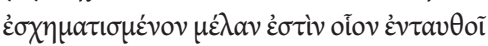

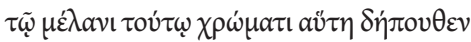

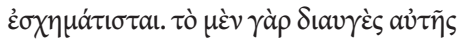

But they say that since the Moon lies between the aether and the air, as the evident junction of both and like a translucent mirror, it receives in itself the impressions of the Earth and the sea, for this very reason a certain dark shadow ${ }^{34}$ manifests itself on it [the Moon]. As I have in mind the best among the scribes-painters of our time, [scribes-painters] our fatherland Thessaloniki happens to be rich in, I mean the one named after lightning and after grace, ${ }^{35}$ what figure the dark [shape] on the Moon happens to assume sometimes, we have only just been able to discern when the air became highly transparent; so such is the dark [shape] configured on the Moon as, for instance, the form it surely assumes here in such black colour. For its [the Moon's] translucent part represents the land, whereas the dark part is an image of the sea. But while the sea in our inhabited world assumes, as you can see, the shape of a human figure and its western part extends, the other [the reflection on the Moon] is configured differently and its eastern part extends. ${ }^{36}$

In this passage, Triklinios introduces all elements that will play a role in the argumentation developed in the rest of the Selenography. First, following Aristotle and Ptolemy, he positions the Moon at the junction of the elemental spheres of air and aether. This will play a role at a later stage of his exposition when he discusses the properties of air and whether air can cast a shadow. ${ }^{37}$ Second, Triklinios compares the

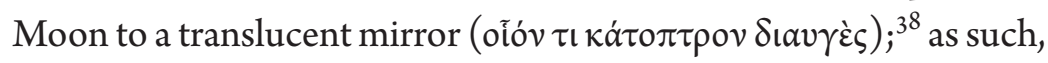
it is able to receive the impressions of the Earth and the sea, which, in turn, is the reason for the appearance of a dark figure onto the Moon.

Triklinios compares the Moon to a mirror and, in doing so, invokes a well-known tradition that is as much literary as it is scientific. In Greek literature and beyond, the image of the Moon as a mirror is among the most stable metaphoric constructs related to the Earth's heavenly companion. Its ubiquity is perhaps equalled only by the conceptualisation of the visible lunar surface as a human face, which is further characterised as bright and beautiful, thus becoming a frequent point of reference in descriptions of female beauty. Further, the idea that the Moon mirrors the relief of the Earth, and especially its outer ocean, is certainly not new in the early fourteenth century. It is already reported by Plutarch in his Concerning the Face Which Appears in the Orb of the Moon where the idea is ascribed to

Interfaces $8 \cdot 2021 \cdot$ pp. 54-73

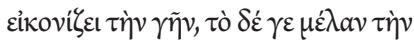
$\theta \dot{\alpha} \lambda \alpha \tau \tau \alpha v . \dot{\alpha} \lambda \lambda^{\prime} \dot{\eta} \mu \dot{\varepsilon} v \dot{\varepsilon} v \tau \tilde{\eta} \kappa \alpha \theta^{\prime} \dot{\eta} \mu \tilde{\alpha} \varsigma$

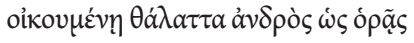
ảं

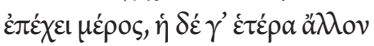

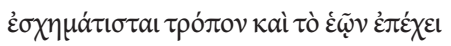
$\mu$ ํ́pos.

37. Postulating that the Moon is surrounded by the elemental sphere of 
the air offers Triklinios the opportunity to discuss the phenomenon of atmospheric refraction, which, however, he does not seize.

38. For the use of the same expression in the preface to the Book of Ceremonies, see Papaioannou $82-83$.

39. On the relationship between Plutarch's Concerning the Face Which Appears in the Orb of the Moon and Triklinios's Selenography, see ní Mheallaigh 199-200. On the doxographer Aëtius (first century CE) who also reports a theory, according to which the markings on the lunar surface are a reflection of the sea that lies beyond the torrid zone of the oikoumene, see ní Mheallaigh 147-49.

40. Further research is needed to trace Triklinios's source.

41. On the ancient tradition of treating the Moon as a "cartographical instrument $[\ldots]$ mirroring back to us parts of our world that were as yet unexplored," see ní Mheallaigh 148-49 with further bibliography. The process of mirroring terrestrially bound subjectivity in Triklinios's Selenography, whether individual or imperial, is further complicated by Triklinios's mirror experiment which I discuss in my forthcoming monograph.
Clearchus (Plutarch, "De Facie" 921B).$^{39}$ An important difference between Clearchus's hypothesis and that elaborated upon by Triklinios is the identification of the water basins whose reflections are seen as dark spots on the lunar surface. According to Plutarch's account, Clearchus thought that what is seen on the Moon is the reflection of the great outer ocean. The continuity of the latter and the discontinuity of the dark patches on the lunar surface, however, form the basis for one of the arguments against Clearchus's theory listed by Plutarch. Triklinios avoids this criticism by stating that the dark anthropomorphic figure is a reflection of the Mediterranean and its adjacent seas, whereas some of the other dark spots visible on the lunar surface would correspond to water basins located further beyond. Therefore, the discontinuities between the dark lunar spots, in Triklinios's rendering of the reflection hypothesis, correspond to the land masses separating the Mediterranean from other oceans and seas (such as the world ocean in the west or the Indian ocean to the east).

It is worth noting another two major differences between the accounts of mirroring we find in Plutarch and in Triklinios. First, Triklinios's exposition describes the dark spots on the lunar surface appearing not as a human face, but as an anthropomorphic figure. The rationale behind this change is the supposed anthropomorphic shape of the Mediterranean..$^{40}$ The focus on the latter is the second notable difference between the two accounts. It could be argued that through his explanation of the dark lunar spots, Triklinios assigns to the Mediterranean a central position within the inhabited world after all, according to the Thessalonian, its reflection is visible on the lunar surface for humankind to see. Thus, on the one hand, Triklinios elevates the status of the Mediterranean on the cosmic scale. On the other, the hypothesis expounded in the Selenography locks down the earthbound and Mediterranean-based (Byzantine) observer in a continuously replicating process of reflection and self-reflection. Directing their gaze upward results in seeing a reflection of themselves, as it were, the lunar mirror redirecting their gaze back upon themselves. $^{41}$

The study of the lunar surface in $\mathrm{BnF} 2381$ does indeed resemble the face of the Moon as observed from the Earth. Understanding, therefore, the function of the diagram as a mirror image of terrestrial geography (real or imagined) and also as an effect of Triklinios's theory of vision is of paramount importance to the interpretation of the Selenography. Further, reconstructing Triklinios's knowledge of reflection, as well as of the casting of shadows, is significant when an-

Interfaces $8 \cdot 2021 \cdot$ pp. 54-73 
42. Wasserstein 164, lines 87-91: virò

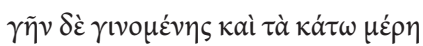

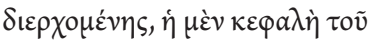

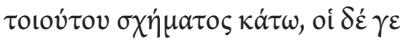

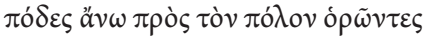

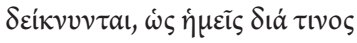

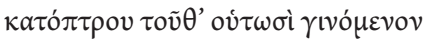

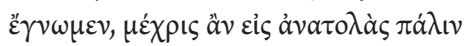

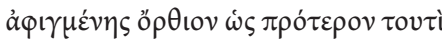

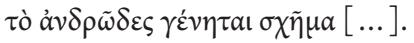

43. We find the same omission on $\mathrm{f} .67 \mathrm{r}$ of the copy of the Selenography in BAV, Barberinianus graecus 16, dating to the third quarter of the sixteenth century and following the model of BSB 482. A digital reproduction in colour is available at DigiVatLib, The Vatican Library; accessed on 31 August 2021. alysing the observational experiment involving the use of a large mirror he describes:

$[\ldots]$ when (the Moon) is below the Earth and is traversing the parts below, the head of this figure is downwards, whereas the feet appear to be looking upwards towards the pole, thus we know that this happens so with the help of a mirror, until when the Moon would arrive again above the horizon, this human-like figure stands upright as before $[\ldots]^{42}$

The analysis of Triklinios's experiment and its possible sources requires a separate detailed examination. Thus, in concluding the present article, I will discuss one final element related to the study of the lunar surface on $\mathrm{BnF} 2381, \mathrm{f} .78 \mathrm{v}$ (figure 4). The question as to how to interpret the omission of the second diagram in Neophytos Prodromenos's copy of the treatise in BSB 482 is further illuminated by a second omission in the text itself. It is worth reminding the reader that contemporary scholarship has underlined the importance of the Selenography as the source that, first, confirmed that Triklinios was a native of Thessaloniki and, second, provided additional evidence for the artistic activity of the Astrapades beyond the decoration of churches in the illumination of scientific manuscripts. It is therefore surprising that, with the exception of Wasserstein and his edition, no contemporary scholar has noted that this precise portion of the text, namely that which refers to the second diagram and mentions Thessaloniki and a collaborator possibly named John Astrapas (11. 6466), is omitted by Prodromenos in BSB 482, f. 93 v. Moreover, as it does not refer to a scribe-painter, BSB 482 maintains the first person

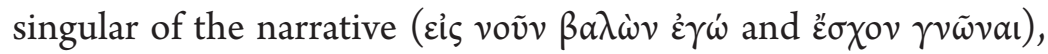
whereas $\mathrm{BnF} 2381$, ff. $78 \mathrm{v}-79 \mathrm{r}$ switches from singular to plural after

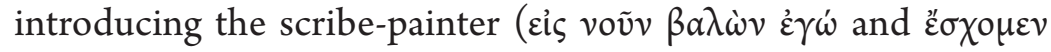

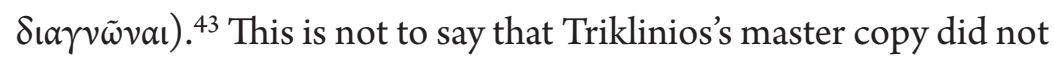
refer to Thessaloniki or to a scribe-painter John Astrapas (?) or a second diagram depicting the lunar surface. The issue certainly merits a detailed analysis, but at present it suffices to suggest that there is a correlation between the mention of the scribe-painter in the narrative and the inclusion of the second diagram, allegedly a product of his artistry. 


\section{Conclusions}

Demetrios Triklinios's Selenography showcases how intricately playful Palaiologan scientific literature could be. In it a familiar literary topos is conflated with ancient theory about the reflective surface of the Moon in order to bring forward the figure of the human observer equipped with their own artificial mirrors. The structure of this short treatise leads the reader from lunar theory to lunar observation. Its diagrammatic content demonstrates Triklinios's commitment to the visualisation of both visible (observable) and invisible (conceptual) cosmological principles. Mirroring is the leitmotif of the Selenography, and it is meaningful beyond the explanations of a mirror experiment in its second half. It is through reflection that the study of the lunar surface becomes contemplation of the terrestrial relief, and of the Mediterranean in particular. As the main premise of Triklinios's discussion is that the lunar surface mirrors that of the Earth, the text reveals not only the desire to observe a celestial object and understand its properties and movement, but also the ambition to perceive the entire world, and, by extension, Byzantium mapped out on a cosmic scale: centrally positioned and perpetually significant.

Bibliography

Acerbi, Fabio. "Byzantine Recensions of Greek Mathematical and Astronomical Texts: A Survey." Estudios bizantinos 4 (2016): 133-213.

Acerbi, Fabio and Inmaculada Pérez Martín. "Les études géométriques et astronomiques à Thessalonique d’après le témoignage des manuscrits: De Jean Pédiasimos à Démétrios Kydônès." Byzantion 89 (2019): 1-35.

Ashbrook Harvey, Susan and Margaret Mullett, ed. Knowing Bodies, Passionate Souls: Sense Perceptions in Byzantium. Washington, DC: Dumbarton Oaks Research Library and Collection, 2017.
Betancourt, Roland. Sight, Touch, and Imagination in Byzantium. Cambridge: Cambridge University Press, 2018.

---. "Why Sight is Not Touch: Reconsidering the Tactility of Vision in Byzantium." Dumbarton Oaks Papers 70 (2016): 1-24. Bianconi, Daniele. Tessalonica nelletà dei paleologi: le pratiche intellettuali nel riflesso della cultura scritta. Paris: EHESS Centre d'études byzantines néo-helléniques et sud-est européennes, 2005.

Boudreaux, Pierre, ed. Catalogus codicum astrologorum graecorum, vol. VIII.3. Brussels: Lamertin, 1912. 
Bydén, Börje. “The Byzantine

Fortuna of Alexander of Aphrodisias' Commentary on Aristotle's

De sensu et sensibilibus." Jahrbuch der Österreichischen Byzantinistik 68 (2018): 93-109.

---. Theodore Metochites' Stoicheiosis astronomike and the Study of Natural Philosophy and Mathematics in Early Palaiologan Byzantium. Göteborg: Acta Universitatis Gothoburgensis, 2003.

Caballero Sánchez, Paula, ed. El Comentario de Juan Pediásimo a los "Cuerpos celestes" de Cleomedes. Edición crítica, traducción y estudio de la transmisión. Madrid: Consejo Superior de Investigaciones Científicas, 2018.

Cacouros, Michel. "Néophytos Prodromènos copiste et responsable (?) de l'édition quadriviumcorpus aristotelicum du 14 siècle." Revue des études byzantines 56 (1998): 193-212.

Cantarella, Merih Danali. Art, Science, and Neoplatonic Cosmology in Fourteenth-Century Byzantium: The Illustrations of Marcianus Graecus 516 (=904).

Doctoral dissertation, Harvard University, Graduate School of Arts \& Sciences 2019.

Caudano, Anne-Laurence. "Cosmologies et cosmographies variées dans les manuscrits byzantins tardifs." Byzantion 85 (2015): 1-25. Cunningham, Ian C. "Greek manuscripts in the National Library of Scotland." Scriptorium 24.2 (1970): 360-71.

Dindorf, Wilhelm, ed. Aristophanis Comoedice. Vol. IV. Oxford 1838.

Drpić, Ivan. "Painter as Scribe: Artistic Identity and the Arts of graphē in Late Byzantium." Word \& Image 29.3 (2013): 334-53.
Eleuteri, Paolo. "I manoscritti dellopera pseudo-aristotelica De virtute." Scripta 9 (2016): 73-88.

Furlan, Italo. "Il libro enciclopedico di maestro Astrapas." Larte di Bisanzio e l'Italia al tempo dei Paleologi 1261-1453. Ed. Antonio Iacobini and Mauro Della Valle. Rome: Argos, 1999. 113-23.

Gaul, Niels. "The Twitching Shroud: Collective Construction of Paideia in the Circle of Thomas Magistros." Segno e testo 5 (2007): 263-340.

---. Thomas Magistros und die spätbyzantinische Sophistik. Wiesbaden: Harrassowitz, 2011.

Gerolemou, Maria and Lilia Diamantopoulou, ed. Mirrors and Mirroring from Antiquity to the Early Modern Period. London: Bloomsbury Academic, 2020. Gerolemou, Maria. "Plane and Curved Mirrors in Classical Antiquity." Mirrors and Mirroring from Antiquity to the Early Modern Period. Ed. Maria Gerolemou and Lilia Diamantopoulou. London: Bloomsbury Academic, 2020. 157-64.

Gerstel, Sharon E. J., Chris Kyriakakis, Konstantinos T. Raptis, Spyridon Antonopoulos, and James Donahue. "Soundscapes of Byzantium: The Acheiropoietos Basilica and the Cathedral of Hagia Sophia in Thessaloniki." Hesperia: The Journal of the American School of Classical Studies at Athens 87.1 (2018): 177-213.

Griebeler, Andrew. "How to Illustrate a Scientific Treatise in the Palaiologan Period." Late Byzantium Reconsidered: The Arts of the Palaiologan Era in the Mediterranean. Ed. Andrea Mattiello and Maria A. Rossi. London: Routledge, 2019. 85-103.
Ierodiakonou, Katerina. "Byzantine Theories of Vision." A Companion to Byzantine Science. Ed. Stavros Lazaris. Leiden: Brill, 2020. $160-76$

Jardine, Boris and Nicholas Jardine. "Critical Editing of Early-modern Astronomical Diagrams." Journal for the History of Astronomy 41 (2010): 393-414.

Jones, Alexander. "Peripatetic and Euclidean Theories of the Visual Ray." Physis 31 (1994): 47-76.

Kessler, Herbert L. "Speculum." Speculum 86 (2011): 1-41.

Kuyumdzhieva, Margarita. “Триликият ангел и триликият Христос [Trilikiyat angel i trilikiyat Hristos; The Three-headed Angel and the Three-headed Christ]." Laudator temporis acti. Studia in memoriam Ioannis A. Božilov. Vol II: Ius, imperium, potestas, litterae, ars et archaeologia. Ed. Ivan A. Biliarsky. Sofia: Izdatelska kăshta "Gutenberg", 2018. 496-525.

Lazaris, Stavros. "Scientific, Medical and Technical Manuscripts." A Companion to Byzantine Illustrated Manuscripts. Ed. Vasiliki Tsamakda. Leiden: Brill, 2017.

Lovino, Francesco. "Un miniatore nella bottega degli Astrapas? Alcune osservazioni attorno alle immagini del Tolomeo Marciano Gr. Z. 516 (904)." Hortus Artium Medievalium 22 (2016): 384-98.

Lundström, Vilhelm. "Neophytos Prodromenos' botaniska namnförteckning." Eranos 5 (1903-04): 129-55.

Manolova, Divna. "Space, Place, Diagram: Cleomedes and the Visual Program of Munich, Bayerische Staatsbibliothek, Graecus 482." The Diagram Paradigm: Cross-Cultural Approaches. Ed. Jeffrey F. Hamburger, 
David Roxburgh, and Linda

Safran. Dumbarton Oaks Byzantine Symposia and Colloquia. Cambridge, MA: Harvard University Press, forthcoming.

Marković, Miodrag. “The Painter Eutychios - Father of Michael Astrapas and protomaster of the Frescoes in the Church of the Virgin Peribleptos in Ohrid." Zbornik Matice srpske za likovne umetnosti 38 (2010): 9-34.

Martin, Jean, ed. Scholia in Aratum vetera. Stuttgart: B.G. Teubner, 1974.

McCarty, Willard. "The Shape of the Mirror: Metaphorical Catoptrics in Classical Literature." Arethusa 22 (1989): 161-95.

ní Mheallaigh, Karen. The Moon in the Greek and Roman Imagination: Myth, Literature, Science and Philosophy. Cambridge: Cambridge University Press, 2020. Mondrain, Brigitte. "Copier et lire des manuscrits théologiques et philosophiques à Byzance." Byzantine Theology and Its Philosophical Background. Ed. Antonio Rigo. Turnhout: Brepols, 2011. 87-107.

---. "La constitution de corpus d'Aristote et de ses commentateurs aux XIII - XIV ${ }^{\mathrm{e}}$ siècles." Codices manuscripti 29 (2000): 11-33.

---. "Les écritures dans les manuscrits byzantins du XIVe siècles. Quelques problématiques." Rivista di studi bizantini e neoellenici 44 (2007): 157-96.
---. “Un lexique botanico-médical «bilingue » dans le Parisinus gr. 2510." Lexiques bilingues dans les domaines philosophique et scientifique (Moyen Âge - Renaissance). Ed. Jacqueline Hamesse and Danielle Jacquart. Turnhout: Brepols, 2001. 123-60.

Nelson, Robert S. “To Say and to See: Ekphrasis and Vision in Byzantium." Visuality Before and Beyond the Renaissance: Seeing as Others Saw. Ed. Robert S. Nelson. Cambridge: Cambridge University Press, 2000. 143-68.

Pàmias Massana, Jordi. "El manuscrito Edimburgensis Adv. 18.7.15 y los Catasterismos de Eratóstenes." Faventia 26.1 (2004): 19-25.

Papaioannou, Stratis. "Byzantine Mirrors: Self-Reflection in Medieval Greek Writing." Dumbarton Oaks Papers 64 (2010): 81-101.

Pentcheva, Bissera V., ed. Aural Architecture in Byzantium: Music, Acoustics, and Ritual. London: Routledge, 2017.

---. Hagia Sophia: Sound, Space, and Spirit in Byzantium. University Park, PA: Pennsylvania State Press, 2017.

---. "Mirror, Inspiration and the Making of Art in Byzantium." Convivium 1.2 (2014): 10-39.

Plutarch. Moralia, Volume XII: Concerning the Face Which Appears in the Orb of the Moon. On the Principle of Cold. Whether Fire or Water Is More Useful. Whether Land or Sea Animals Are
Cleverer. Beasts Are Rational. On the Eating of Flesh. Translated by Harold Cherniss, W. C. Helmbold. Loeb Classical Library 406. Cambridge, MA: Harvard University Press, 1957. 34-223.

Pérez Martín, Inmaculada and Divna Manolova. "Science Teaching and Learning Methods in Byzantium." A Companion to Byzantine Science. Ed. Stavros Lazaris. Leiden: Brill, 2020. 53-104.

Reynolds, Leighton D. and Nigel G. Wilson. Scribes and Scholars: A Guide to the Transmission of Greek and Latin Literature. Second and revised edition. Oxford: Clarendon Press, 1975.

Smith, Ole Langwitz. Studies in the Scholia on Aeschylus. I: The Recensions of Demetrius Triclinius. Leiden: Brill, 1975.

Trapp, Erich, Rainer Walther, Hans-Veit Beyer and Christian Gastgeber, ed. Prosopographisches Lexikon der Palaiologenzeit. Vienna: Verlag der Österreichische Akademie der Wissenschaften, 2001.

Wasserstein, Abraham. "An Unpublished Treatise by Demetrios Triklinios on Lunar Theory." Jahrbuch der Österreichischen Byzantinistik 16 (1967): 153-74. Wilson, Nigel G. "Planudes and Triclinius." Greek, Roman and Byzantine Studies 19.4 (1978): 389-94. 